\title{
Landscape Simulation for Restoring Borrowed Scenery of a Japanese Garden Using a Terrestrial Laser Scanner
}

\author{
早瀬 真弓* 今西 純一** 中村 彰宏*** 戸田健太郎*** 森本 幸裕 ${ }^{* *}$ \\ Mayumi HAYASE Junichi IMANISHI Akihiro NAKAMURA Kentaro TODA \\ Yukihiro MORIMOTO
}

\begin{abstract}
A terrestrial laser scanner provides detailed and highly accurate 3D data rapidly and is widely applied in various situations. In this study, we surveyed the Seifuso Garden designated as a place of scenic beauty by the national government. We acquired point-data having information of 3D coordinates and colors by a terrestrial laser scanner and simulated the scenic views from the garden for restoring the borrowed scenery. As a result, we confirmed the positional relationship of the garden, the buildings around the garden and the Higashiyama Mountains at the selected view points. The simulated results were useful for the garden management, especially for trimming the trees within the garden in consideration of hiding the near-by tall buildings. We also found the influence on the scenic views from the garden if the buildings in this area were built at the maximum height allowed by the zoning regulation of the Kyoto City. A terrestrial laser scanner was considered to be a novel and effective tool for landscape simulation.
\end{abstract}

Keywords: terrestrial laser scanner, landscape simulation, borrowed scenery, landscape regulation, scenic view キーワード：地上型レーザースキャナ，景観シミュレーション，借景，景観規制，眺望景観

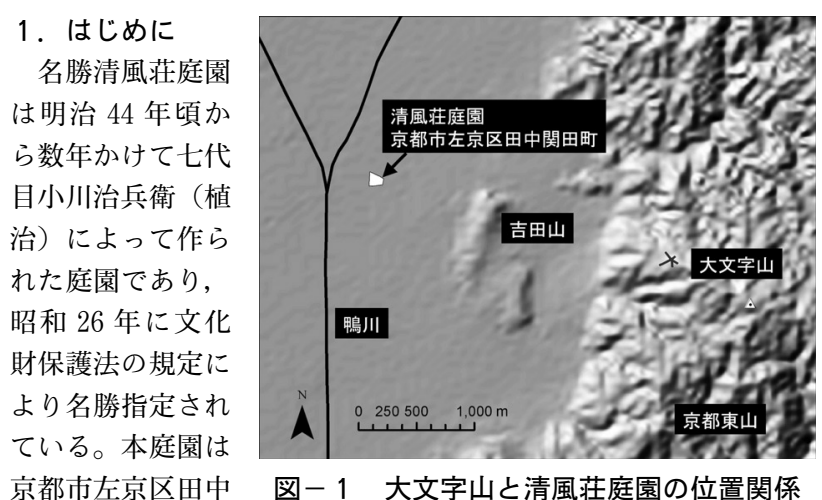
関田町に位置し

（図－1），植治による庭園の特徴のひとつである京都東山の借景, すなわち五山の送り火で有名な大文字山やその周辺の山並みを庭 園の風景に取り込む工夫のなされた名庭である。しかし, 近年成 長しすぎた樹木によって大文字山が見えない状態となるなど維持 管理は十分と言えず，作庭当初の風趣が失われつつある。現在は 所有者である京都大学を中心に庭園の修復整備事業が進められて いるが，成長しすぎた樹木を切り下げる際には，作庭当初は存在 しなかった近隣の高い建築物への視線を遮蔽しつつ借景の復元を する必要がある。本件のような場合, 事前に様々な視点や角度か らの景観に配慮した植栽管理を検討するために景観シミュレーショ ンを行うことが有用であると考えられる。

庭園の景観シミュレーションの方法として，フランスの熱帯農 業開発センター（CIRAD）が開発した植物形状モデリングシス テムであるAMAPなどを用いた研究が多くなされている ${ }^{1-5)}$ 。 しかし，AMAPなどの手法による景観シミュレーションでは, 予め庭園内で毎木調查などを行い，どのような樹木があるのかと
いう事前情報が必要である ${ }^{2-5)}$ 。また，庭園における樹木の実際 の形状や刈り込みなどを再現することは難しく ${ }^{2)}$, 庭園内におけ る樹木がライブラリに存在しない場合には，代替植物を用いるこ とになる ${ }^{2-5)}$ 。また, 借景庭園の眺望保全の研究としては, 借景 庭園から見える地形と建築物に関しての報告 ${ }^{6)}$ などがあるが, 植 物を含めた 3 次元モデルは構築されていない。

一方，近年新しい測量方法としてレーザースキャナが用いられ るようになっている。レーザースキャナによって, 離れた地点か ら短時間でかつ精確に対象物の 3 次元座標を測量することが可能 であり, 現在様々な場面で利用されている。また地上型レーザー スキャナは, 航空機搭載型のレーザースキャナと比べて測量でき る範囲は狭いものの, 数 $\mathrm{mm}$ 単位で測量でき, 位置センサを必 要としないことや飛行中のブレもないため, より精確なデータが 得られ, 地形の計測が困難な急崖地での測量 ${ }^{7)}$, 災害観測調查 ${ }^{8)}$, 微地形計測 $\left.{ }^{9}\right)$ などの調查研究が行われている。庭園においては測 量に用いられつつあるが，景観シミュレーションに応用した研究 事例はまだない。

そこで本研究では地上型レーザースキャナを用いて, 清風荘庭 園における借景復元に関する景観シミュレーションを行い，その 実用性について考察することを目的とした。さらに，地上型レー ザースキャナによって得られたデー夕を用いて，庭園周辺に現在 の京都市の都市計画で許容されている高さの建築物が建てられた 場合，庭園からの眺望景観にどのような影響があるかを検討した。

\section{2. 方法}

（1）地上型レーザースキャナによる測量

測量は樹木落葉前（平成 19 年 10 月 30 日／測量日 I ）および 樹木落葉後（平成 20 年 1 月 25 日／測量日 II）に計 2 回行った。 測量日 I には庭園内外 14 筒所，測量日 II には庭園内外 9 筒所,

${ }^{*}$ 京都大学大学院農学研究科 ${ }^{* *}$ 京都大学大学院地球環境学堂 ${ }^{* * *}$ 大阪府立大学大学院生命環境科学研究科 
計 23 箇所で行った。いずれの測量も午前 9 時から午後 5 時の間 に行われた。なお測量日 I の天気は是り時々晴れ, 測量日 II の 気は晴れ時々雪であった。測量には地上型レーザースキャナ （Riegl 社 LMS-Z420i）を用いた。本研究で用いた測器は鉛直方 向に $80^{\circ}$, 水平方向に $360^{\circ}$ の測定範囲について最小 $0.004^{\circ}$ ステッ プでスキャンすることができる。レーザーの波長は $1550 \mathrm{~nm}$ ，ビー

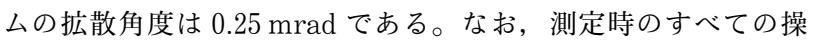
作は測器と LAN で接続されたノートパソコンより専用ソフトウェ ア（Riegl 社 RiSCAN PRO）を用いて行った。清風荘庭園敷地 内の建築物内各地点からは約 160 万点ずつ, 敷地内庭園各地点か らは約 310 万点ずつ, 敷地外各地点からは約 160 万点ずつ, 3 次 元座標をもつ点群デー夕を取得した。

（2）取得したデータの統合と処理

地上型レーザースキャナによって得られた庭園内外の 3 次元座 標データと, トータルステーションで位置測量を行った測量基準 物のデータを用いて, 公共座標系への統合を行い, 測量日ごとの プロジェクトファイルを作成した。さら測器に取り付けられたデ ジタルカメラの写真からの色情報をデータに付加し, 全地点のデー 夕の統合を行った。上記の処理の間に, データの圧縮や不要部分 の削除を適宜行った。

\section{（3）京都東山の標高データ及び清風荘庭園の周辺建築物データ} の作成

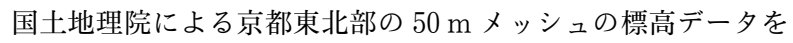

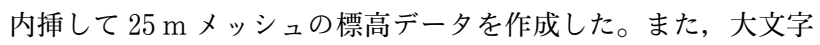

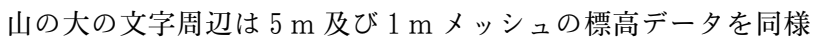
に作成した。これらのデータを専用ソフトウェアに読み込ませる ことで, 庭園のデー夕との合成を行った。そして, 得られたデー 夕を部分的に切り出して CAD ソフトに読み込ませ, 断面図に加 工した。

現在，清風荘庭園近隣は，京都市都市計画によって $15 \mathrm{~m}$ 第 2 種もしくは $15 \mathrm{~m}$ 第 4 種高度地区に指定されており, 建築物の高 さは $15 \mathrm{~m}$ ，さらにその上部の塔屋部分は $3 \mathrm{~m}$ まで許容されてい $3^{10,11}$ 。そこで, 京都市都市計画図と国土地理院の $5 \mathrm{~m}$ メッシュ の標高デー夕を用いて, 周辺の建築物が京都市の都市計画で許容 されている最大の高さとなる場合の仮想建築物デー夕を作成した。 なお，作成した画像をわかりやすくするにあたっては画像処理ソ フト (Adobe 社 Adobe Photoshop, Adobe Illustrator) を用 いた。

\section{(4) 実際の施業結果とシミュレーション結果の比較}

清風荘庭園では実際に樹木切り下げの施業が行われたため, 同 じ視点における景観シミュレーションの結果と施業後の写真との 比較を行った。

\section{3. 結果}

\section{(1) 取得したデータ}

地上型レーザースキャナを用いて測量を行った結果, コンピュー 夕上で庭園景観は図-2のように再現された。基本的に池の部分 のデータは得られなかったが, 測量地点によっては水面でレーザー が鏡面反射することによって水面より下に倒立した樹木等が記録 された（図一2)。測量日 IIの天候の降雪時のデータには雪のデー 夕が含まれていた。これらのデータはノイズとして除去する必要 があった。また, 今回の測量で得た点群デー夕において測器から の最長距離は約 $600 \mathrm{~m}$ であった。

\section{(2) データの合成}

地上型レーザースキャナによって得られたデー夕と京都東山の 標高デー夕は図一 3 のように合成された。以下, 清風荘庭園内の 主な視点である庭園内芝生広場及び庭園内建築物 2 階から（図一 4 ）の眺望景観について結果を示す。庭園内の景観と周辺建築物

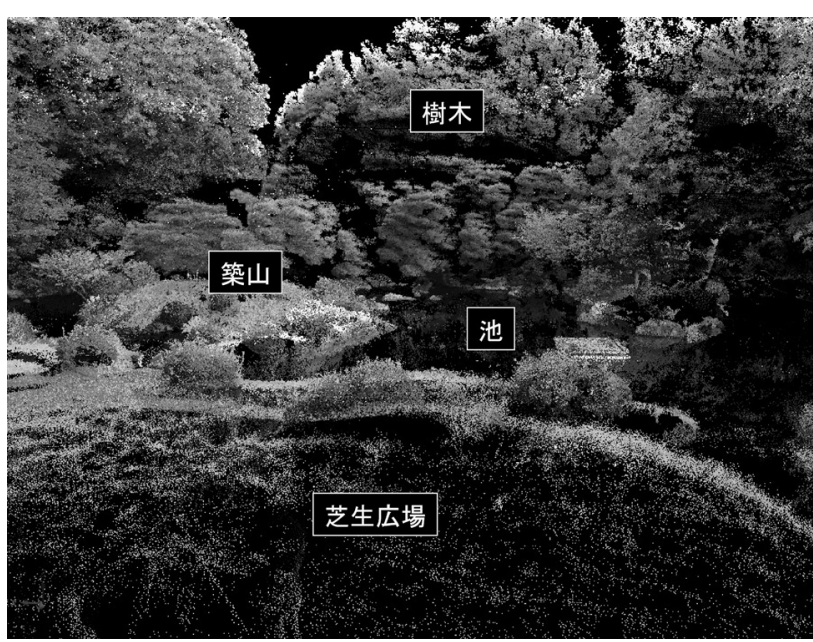

図ー２＼cjkstart地上型レーザースキャナで得られた庭園内の景観

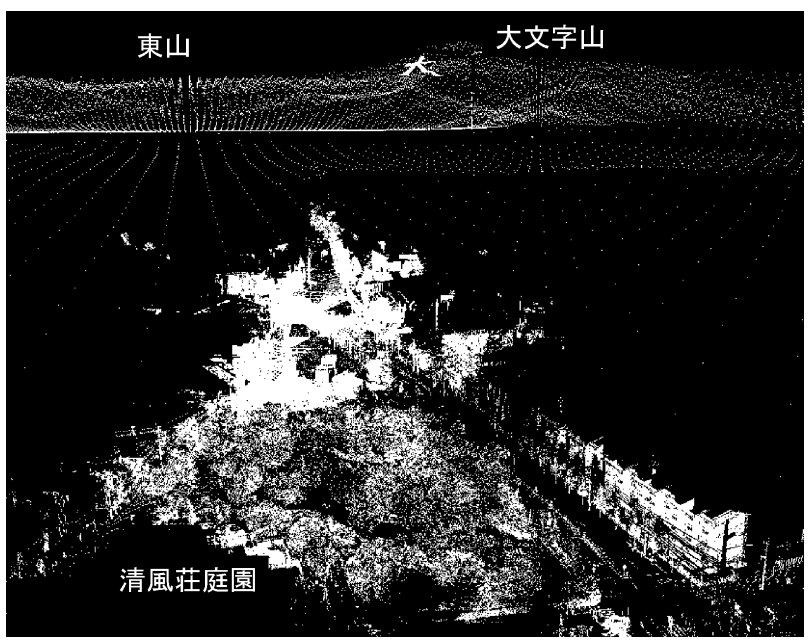

図ー3＼cjkstart地上型レーザースキャナのデータと 東山の標高データの合成

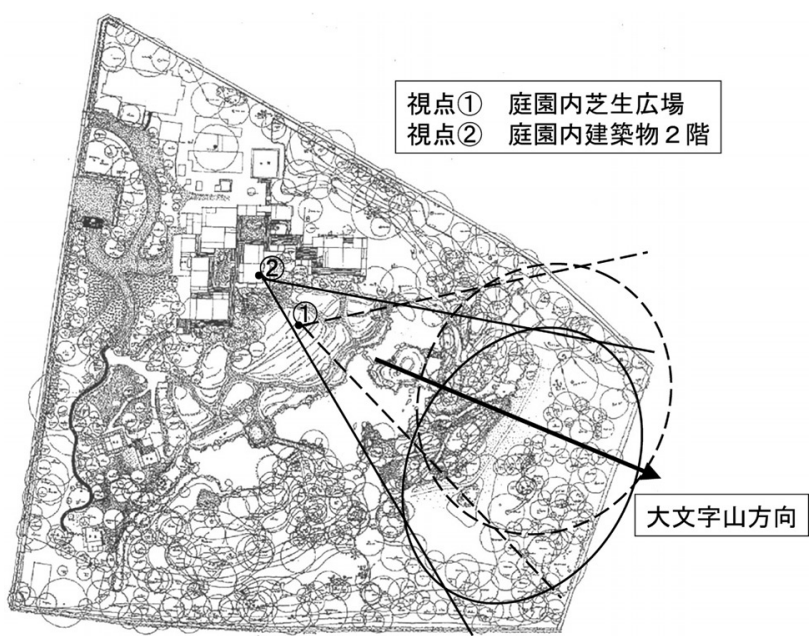

図 $-4 \quad$ 清風荘庭園内の主な視点

のデータや標高データを重ね合わせると, 実際には樹木で隠れて いる東山の山並みや周辺建築物は図－5，6のように表現された。 これらの合成画像から樹木を切り下げる方法が検討され，例えば 庭園近隣のある建築物が大の字の右払いにかかることなど具体的 な問題点も把握された。このように複数の視点からの眺望景観を 


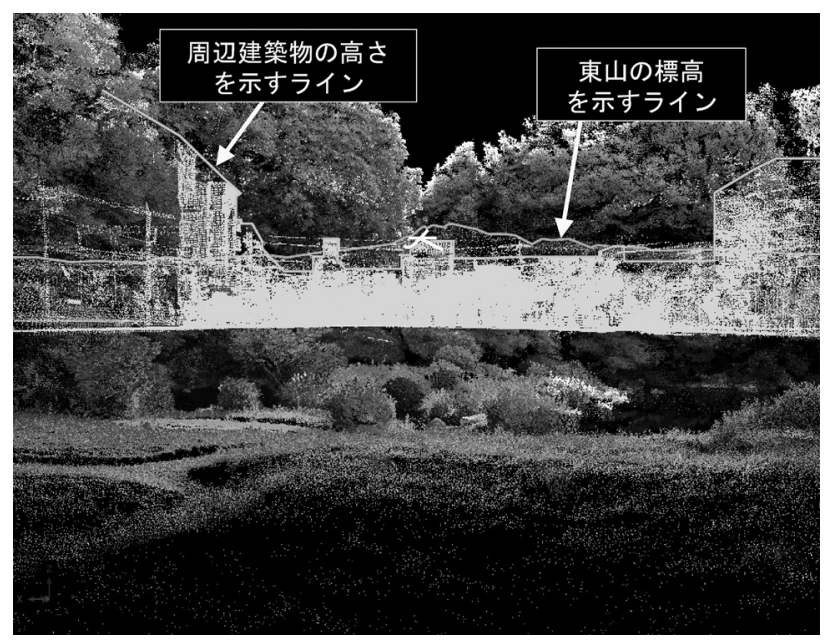

図- 5 視点(1)からの眺望景観

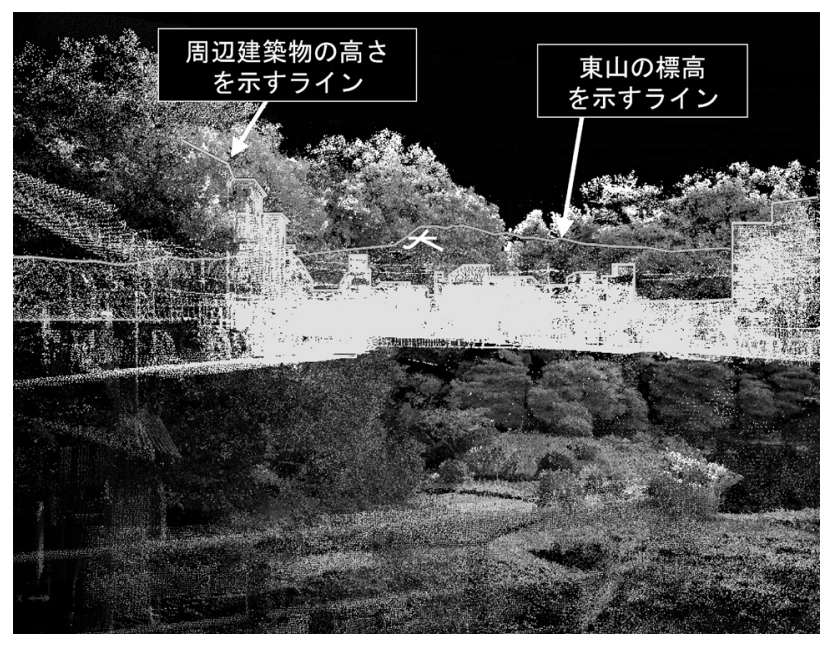

図-6 視点(2)からの眺望景観

表示させることにより，それぞれの地点から眺望景観に影響を与 える庭園周辺のいくつかの建築物や看板等が抽出された。

（3）樹木の切り下げシミュレーション

庭園の景観と近隣の建築物，東山の山並みの位置関係を予め把 握した上で, 地上型レーザースキャナによって得られたデー夕を 部分的に削除し, 樹木の切り下げシミュレーションを行った（図一 7, 8)。視点(1)から大文字山の大の文字が見えるようにするた めには, 該当部分の樹木は最大約 $5.5 \mathrm{~m}$ 切り下げる必要があった。 視点(2)ら同方向を眺望するにあたっては大文字山の大の文字と 重なる部分の樹木を約 $5 \mathrm{~m}$ 切り下げると, 近隣の建築物を遮蔽 しつつ東山への眺望を確保できることがわかった。

なお, シミュレーションを行った結果を活かし, 実際に庭園内 で施業が行われ, 大文字山への眺望景観が復元された。施業の途 中ではあるが, 庭園内の芝生広場から大文字山が見えるようになっ た（写真－1）。この写真との比較により, データの合成によっ て示された庭園景観と東山の山並みの位置関係は, 実際とずれて いないことが確認された。

\section{（4）清風荘庭園の周辺建築物}

地上型レーザースキャナによって得られたデータを断面図にし, 大文字山までの眺望について検討を行った結果, 東大路通り以西, 特に庭園の近隣に位置する $10 \mathrm{~m}$ 以上の建築物が眺望景観に大き な影響を与えることがわかった（図－9）。また，清風荘庭園周 辺に現在許容されている高さの建築物のデータを表示したところ

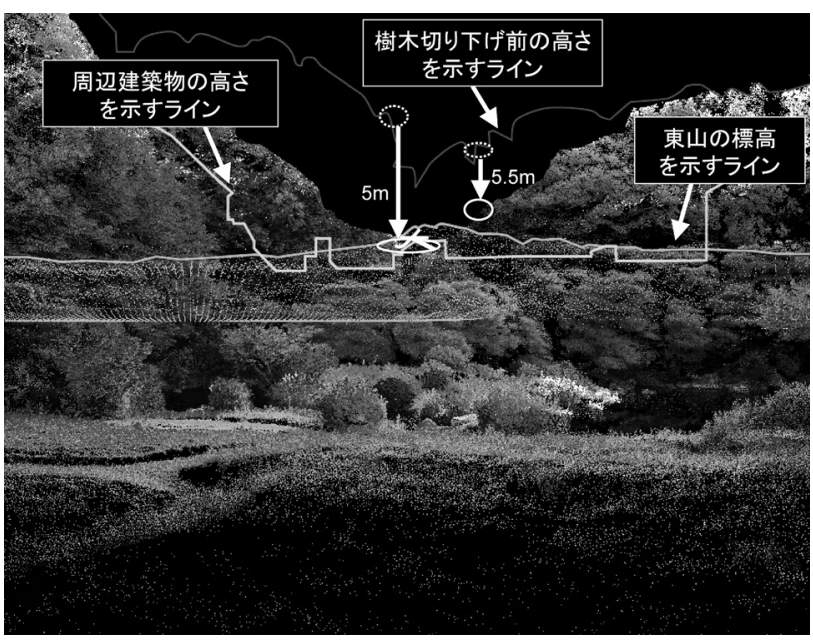

図ー 7 視点(1)における樹木切り下げシミュレーション

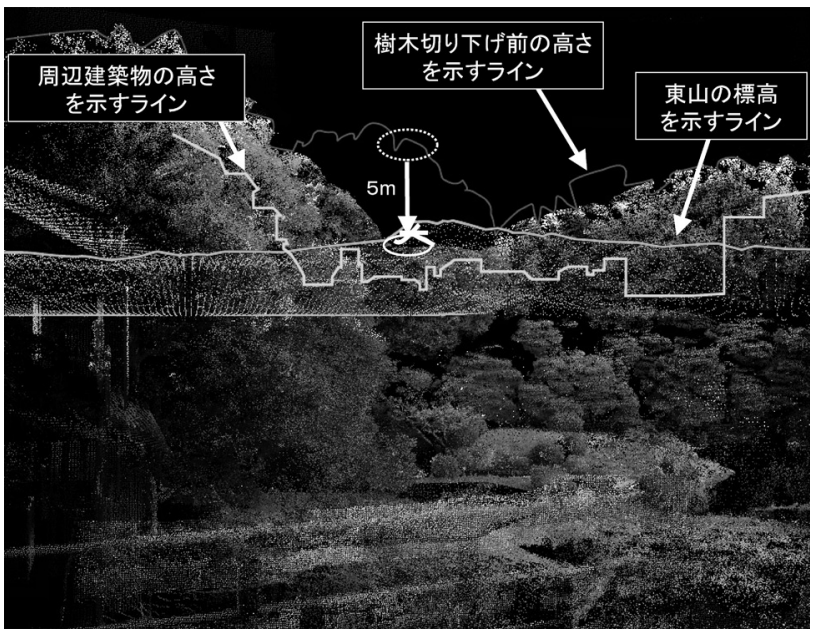

図ー8＼cjkstart視点(2)における樹木切り下げシミュレーション

図ー10のようになった。さらに, 眺望景観に最も影響を与えて いる，地区 A及び地区 B（図一-11）の建築物の高さ規制を現状よ り強め, 塔屋部分も含めて地区 $\mathrm{A}$ は高さ $10 \mathrm{~m}$ 以下, 地区 $\mathrm{B}$ は高 さ $12 \mathrm{~m}$ 以下とした場合，図-12 のとおりとなった。

\section{4. 考察}

（1）地上型レーザースキャナを用いた景観シミュレーションの 実用性

本研究では地上型レーザースキャナによって得られた清風荘庭 園及びその周辺の建築物データと国土地理院の標高デー夕を用い て, 借景復元に関する景観シミュレーションを行った。図ー 5 , 6 で示したように地上型レーザースキャナで得られた庭園及び周 辺建築物のデー夕と東山の標高デー夕を重㸚わせることで, そ れぞれの正確な位置関係を捉え, 東山, 特に大文字山が見えるよ うにするためにはどの程度樹木を切り下げればよいかということ や, 庭園近隣のある建築物が大の字の右払いにかかってしまうこ となどを予め具体的に把握することができた。また，図一 7,8 のように部分的にデータを削除して庭園内の樹木の切り下げシミュ レーションを行い，切り下げた場合の眺望景観について検討する とともに切り下げる樹木の高さについて具体的な数值を示すこと ができた。庭園内で維持するべき樹木の高さを示せば，本庭園の 今後の維持管理に活かすことができると考えられる。これらの結 果より, 地上型レーザースキャナを用いた名勝清風荘庭園におけ 


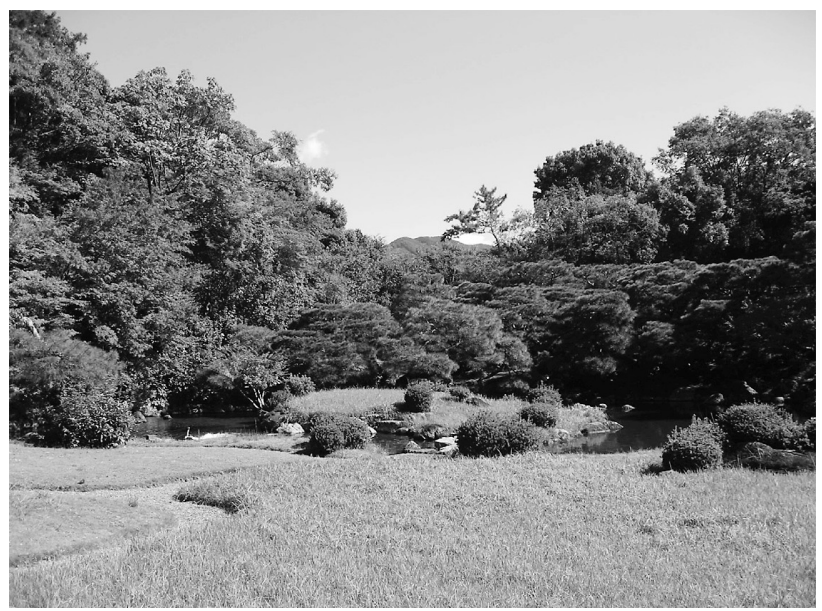

写真 -1 清風荘庭園と大文字山 2008.10 .15 撮影

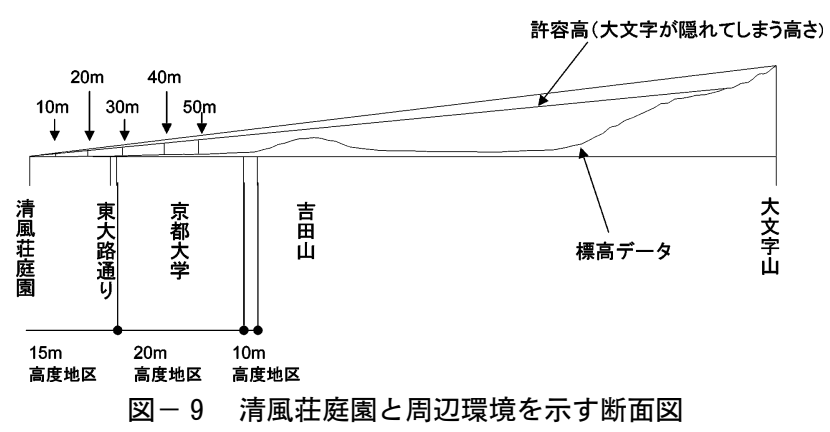

る京都東山の借景復元に関する景観シミュレーションは, 任意の 視点から近隣の高い建築物を考慮しながら, 東山への眺望を阻害 していた樹木を切り下げる際の資料として有用であったと考えら れた。

測量においては計測対象物の表面がレーザー光線を吸収または 散乱してしまうような素材である場合は計測できないため, 池の 部分のデー夕を得ることはできなかった。池の水面では, レー ザーが鏡面反射することによって, 樹木等が倒立している状態の デー夕が取得されたため，これらのデータの除去が必要となった。 また，霧中，降雨，降雪の天候下で計測を行うとノイズが発生す るため, 測量日 II の天候の降雪時のデー夕にはノイズ除去の作業 が必要であった。測定距離には制限があり, 今回の測量で得たデー

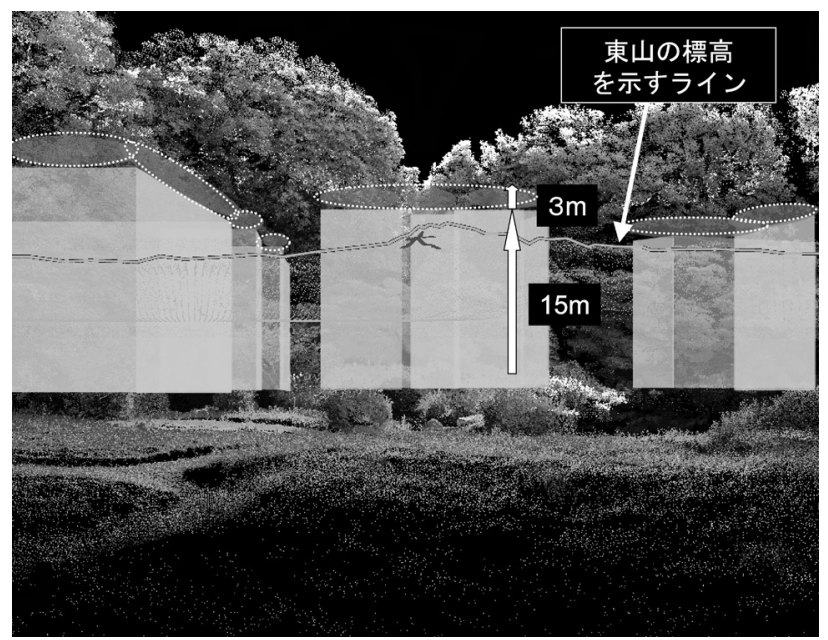

図-10 現状の都市計画で許容されている高さの 建築物が建てられた場合

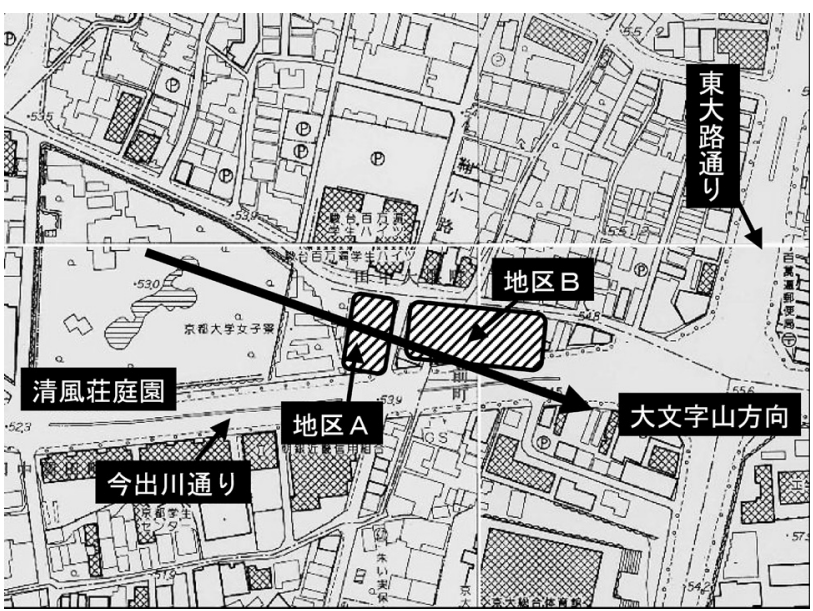

図-11 清風荘庭園からの眺望景観に 特に影響を与える地区

夕において測器からの最長距離は約 $600 \mathrm{~m}$ であった。本手法に は測量について機器の特性上このような制約もあるが，今後庭園 における景観シミュレーションに十分に活用できると考えられた。

また，実際に庭園内で行われた施業後の写真（写真－1）之樹 木切り下げシミュレーション画像（図－7）との比較により, 庭 園景観と東山の山並みの位置関係の確認を行った結果，本手法で 得られた情報は実際とずれていないことがわかった。本手法のよ うに現実に即した精確なデー夕に基づく景観シミュレーションは, 信頼性が高いと言える。景観シミュレーションの意義を考えると, シミュレーション結果の信頼性が高いことは重要であり, 今後本 庭園の整備事業に関する情報を公開し，事業についての評価を行 う際にも役立つと考えられる。また，座標の統合が正確に行える という点においては，本件のように周辺の建築物を考慮した景観 シミュレーションを行うにあたり有利である。さらに，樹木や建 築物等の形状を一つ一つモデリングする必要が無いため, 他の景 観シミュレーションと比べて労力が大幅に少なくて済むことも大 きな利点である。以上から，本研究により新たな手法を用いた景 観シミュレーションの有用性を示すことができた。

\section{（2）清風荘庭園からの眺望景観に周辺建築物が及ぼす影響}

地上型レーザースキャナによって得られたデー夕を断面図に加 工し，大文字山までの眺望について検討を行った結果，東大路通 り以西に位置する $10 \mathrm{~m}$ 以上の建築物が眺望景観に大きな影響を 与えることがわかった（図－9）。この地域は，京都市都市計画

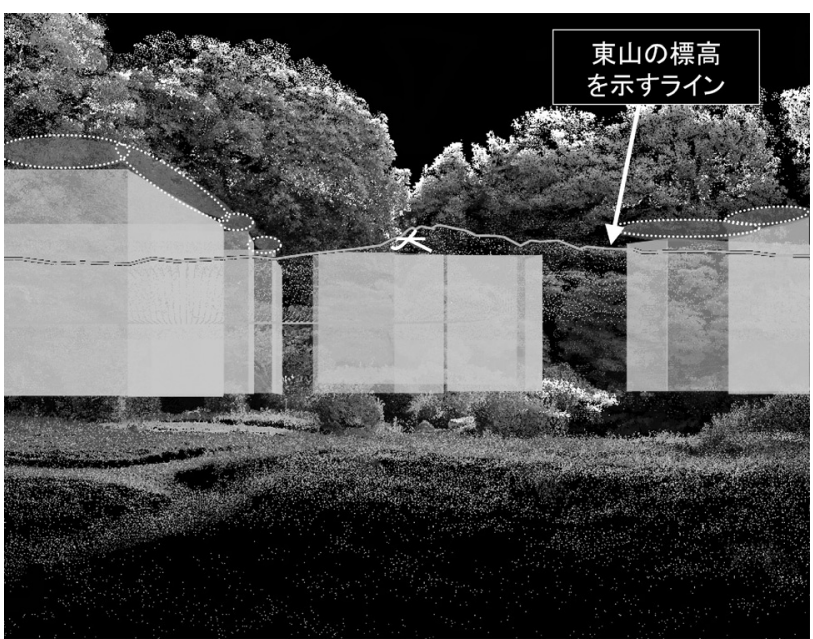

図ー12＼cjkstart眺望に特に影響を与える地区の建築物の 高さ規制を強めた場合 
によって $15 \mathrm{~m}$ 第 2 種もしくは $15 \mathrm{~m}$ 第 4 種高度地区に指定され ているが ${ }^{10,11)}$, 現在許容されている高さの建築物が建てられると, 庭園からの眺望景観に大きな影響があることが明らかになった （図-10）。現在の京都市の清風荘庭園周辺における建築物の高さ に関する規制では，本庭園からの眺望景観は保全できないことが わかった。特に大文字山への眺望景観に影響を与える地区 A， B （図－11）の建築物の高さ規制を現状より強めた場合のシミュレー ションを行った結果, 塔屋部分も含めて, 地区 $\mathrm{A} は$ 高さ $10 \mathrm{~m}$ 以 下, 地区 $\mathrm{B}$ は高さ $12 \mathrm{~m}$ 以下に抑えれば, 清風荘庭園からの大文 字山の大の字への眺望が確保されることがわかった（図－12）。 以上の結果より, 本手法は庭園内の重要な視点からの保全すべき 眺望を確保するために必要な行政上の措置を検討する上でも有効 であることが示された。京都市では平成 19 年に京都市眺望景観 創生条例を制定している。この条例は, 特定の視点場から特定の 視対象を眺めるときに視界に入る建築物等の高さ, 形態及び意匠 について必要な事項を定めることにより, 京都の優れた眺望景観 を創生するとともに，これらを将来の世代に継承することを目的 としており ${ }^{12)}$, 現在 38 箇所が対象地として指定されている ${ }^{13)}$ 。名 勝指定を受けている本庭園の眺望景観を保全するためには, 京都 市眺望景観創生条例によって眺望景観保全地域に指定し，近隣の 一部の地域については建築物の高さ規制を現状よりも強めること が考えられる。

\section{（3）本手法の活用法について}

本研究で得られた景観シミュレーションの結果は, 清風荘庭園 の整備活用事業の参考資料として用いられた。実際に資料として 用いられる中では， 2 次元の資料だけではイメージがわきにくい ことも, 立体的な 3 次元情報を提示することによって誰にでも分 かり易く感じられ，客観的な景観検討を行うことができたといっ た感想も聞かれた。地上型レーザースキャナによって得られる精 確なデー夕に基づいたシミュレーションは, 関係者が合意形成を はかった上で事業を進めていくことに有用である可能性がある。 また, 名勝に関する記録は, 内容を理解し, 適切に保存管理して いく上で必須であり ${ }^{14}$ ), 今後本手法を文化財庭園名勝の貴重な記 録方法として活用することが期待される。庭園の整備事業におい ては, 作庭者の意図したデザインを的確に捉え, できる限り作庭 当時の状沉を復元することが求められる。現存する清風荘庭園の 史料から作庭当時の様子を明らかにする研究と連携していくこと で, さらに意義の深い景観シミュレーションを行うことができる と考えられる。

\section{引用文献}

1 ) 本條毅・斎藤馨・熊谷洋一（1992）：植物形状モデリングと その可視化による景観予測に関する考察：造園雑誌 55(5),
301-306

2 ）森本幸裕（1993）：植物モデリングによる緑化景観予測シス テムの応用について：日本緑化工学会誌 18(3)，162-167

3 ）森本幸裕（1993）：植物モデリング・可視化システムを用い た桂離宮庭園の植生景観のシミュレーション：造園雑誌 57 (2), 113-120

4 ) 中島義晴（1999）小石川後楽園における眺望景観保護のため の景観シミュレーション手法に関する基礎的な研究 : 東京大 学修士論文

5 ）林恩美・本條毅・丸田頼一（2000）：VRML 之植物形状デー タベースによる景観可視化手法に関する研究：ランドスケー プ研究 63(5), 799-802

6 ）上山文子・飯塚英雄 : 借景庭園から見える地形のコンピュー 夕ーによる分析研究（1998）：日本建築学会大会学術講演梗 概集. A-2，防火，海洋，情報システム技術 vol.1998，487488

7 ) 坂田聖二・横田修一郎・佐名木哲二（2007）：地上型レーザー スキャナによる急崖上のタフォニの検出：情報地質 18(2), 128-129

8 ）松田重雄（2005）：地上型レーザースキャナーによる災害観 測調査：写真測量とリモートセンシング 44(2), 22-25

9 ) 戸田健太郎・中村彰宏・前中久行（2007）：地上型 3D レー ザースキャナを用いた男里川河口の微地形計測之潮間帯の冠 水特性の評価：ランドスケープ研究 70(5)，463-466

10）京都市都市計画情報 用途地域・高度地区：京都市都市計画 情報等の検索 : ホームページ

<http://www5.city.kyoto.jp/tokeimap/>, 2008.12.19 参照

11）高度地区計画書 : 景観関連条例・規則集 都市計画の計画書 : 京都市情報館ホームページ

<http://www.city.kyoto.lg.jp/tokei/page/0000023511.ht $\mathrm{ml}>, 2008.8 .4$ 更新, 2008.12.19 参照

12）京都市眺望景観創生条例：景観関連条例・規則集 眺望景観 関係：京都市情報館ホームページ

$<$ http://www.city.kyoto.lg.jp/tokei/page/0000023511.ht $\mathrm{ml}>$, 2008.8.4 更新, 2008.12.19 参照

13）京都市眺望景観創生条例に基づく眺望空間保全区域等の指定 等（告示）：景観関連条例・規則集 眺望景観関係：京都市 情報館ホームページ

$<$ http://www.city.kyoto.lg.jp/tokei/page/0000023511.ht $\mathrm{ml}>, 2008.8 .4$ 更新, 2008.12.19 参照

14）中島義晴（2008）：名勝の価值を記録する：月刊文化財 No.538 55-56

（2008.12.25 受付， 2009.7.25 受理） 